Dorota Tomczyszyn

Państwowa Szkoła Wyższa

im. Papieża Jana Pawła II

w Białej Podlaskiej
Kiedy myślimy Rodzina..., red. M. Duda,

K. Kutek-Sładek, Kraków 2016, s. 231-248

(Praca Socjalna w Teorii i Działaniu, 2).

DOI: http://dx.doi.org/10.15633/9788374385091.17

\title{
Trudności w realizacji ról rodzicielskich rodziców dzieci z niepełnosprawnością intelektualną
}

Difficulties in realization of parental roles of parents of children with intellectual disabilities

\begin{abstract}
The paper presents the results of research on difficulties in realization of parental roles of parents of children with intellectual disabilities. The author has surveyed 222 parents of children with intellectual disabilities, including 111 mothers and 111 fathers. The research was completed in 2013 and 2014 in the Lublin Province. On the basis of parents' declarations it can be seen that most respondents did not encounter dif-
\end{abstract}

ficulties in the professional sphere or the sphere of marriage, but in tasks connected with raising a child with a disability. Problems that appear in parenting children with disabilities concern most often health care services, rehabilitation and the way the disabled are treated by others.

Keywords: child with a disability, mental disability, family

\section{Makrospołeczny wymiar współczesności a rodzina}

Nie można oprzeć się wrażeniu, że dynamika przemian rodziny odpowiada dynamice przeobrażeń postępu naukowo-technicznego i zjawisk o podło- 
żu ekonomiczno-społecznym. Dawniej były to urbanizacja i industrializacja, a dzisiaj ruchliwość społeczna, nowe warunki społeczno-ustrojowe, informatyzacja w technice, przemiany medyczne, a także uniezależnianie się człowieka od otoczenia ${ }^{1}$. Jakie jeszcze współczesne uwarunkowania społeczne kreują rzeczywistość rodzinną?

W świecie konsumpcji, szybkiej zmiany, kultury instant człowiek jawi się jako istota skazana na zagubienie, bezradność. Świat, w którym żyje, nie daje stałych wartości i drogowskazów. Przykładem tej sytuacji staje się fakt, że przeciętny człowiek czuje się wartościowy, a nawet „szczęśliwy”, gdy traci pieniądze, zaopatrując się w kolejne produkty czy kupując drugi i trzeci samochód. Dawid Tetzlaff twierdził, że „logika kultury współczesnej wyznaczona jest przez zjawisko nieograniczonej konsumpcji. A więc konsumpcja przyjęła rolę produkcji, stając się główną perspektywą postrzegania zjawisk społecznych. Współczesne społeczeństwa można nazwać «społeczeństwem spektakli opartych na konsumpcji»"2. W tym świecie wszystko się zmienia; reklamy wpływają na nasze wybory, liczy się młodość, piękny wygląd. Tożsamość człowieka dawniej symbolizowały przede wszystkim cechy umysłu i serca, pozycja społeczna, trwałe więzi międzyludzkie. W społeczeństwie konsumpcji natomiast ludzie coraz częściej postrzegani są przez pryzmat swoich ciał$^{3}$. Cechą współczesnej kultury popularnej jest także kult ciała i seksualności. Zdaniem Zbyszka Melosika swobodne podejście młodego pokolenia do seksu, „luźna obyczajowość" to postawa, którą "można bez trudu wyprowadzić z pewnych, wyraźnie zaznaczających się w kulturze współczesnej tendencji: orientacji na ciało i seksualizacji konsumpcji oraz przymusu udanego życia seksualnego"

Zofia Frączek artykułuje dysfunkcjonalne zjawiska zagrażające rodzinie:

- ograniczenia we wspólnym spędzaniu czasu wolnego, aktywizacja zawodowa matek;

- brak dialogu w rodzinie, który uniemożliwia zaspokajanie potrzeb emocjonalnych i społecznych członków rodziny;

- powierzenie wychowania „elektronicznym wychowawcom” (komputery, telewizja), które szerzą relatywizm moralny;

- wzrost bezrobocia, co wpływa często na powstawanie konfliktów w rodzinie;

1 Z. Bielan, Zagrożenia i kryzys wspótczesnej rodziny, [w:] Pedagogika rodziny na progu XXI wieku. Rozwój, przedmiot, obszary refleksji i badań, red. W. A. Janke, Toruń 2004, s. 246.

2 D. Tetzlaff, Divide and conquer: popular culture and social control in late capitalism, "Media, Culture and Society" 13 (1991) nr 1, s. 14-15.

3 D. Tomczyszyn, Dzieci z upośledzeniem umysłowym w środowisku szkolnym - refleksje nauczyciela, Biała Podlaska 2012, s. 34.

4 Z. Melosik, Kultura popularna jako czynnik socjalizacji, [w:] Pedagogika społeczna, red. B. Śliwerski, Z. Kwieciński, Warszawa 2003, s. 78. 
- niedostateczne przygotowanie młodego pokolenia do życia w małżeństwie i rodzinie, niska świadomość wychowawczą rodziców;

- wzrost liczby konfliktów w rodzinie, osłabienie więzi między jej człon$\mathrm{kami}^{5}$.

Makrostrukturalne procesy zachodzące w społecznościach narodowych i międzynarodowych, wywołujące przemiany społeczno-gospodarcze, wywierają wpływ na sytuację bytową współczesnych rodzin i realizację ich funkcji. Polityka społeczna, gospodarcza, transformacje systemowe mają wpływ na fakt, że wiele rodzin w problemy egzystencjalne, materialne, niszczą całe struktury rodzinne. Polskie rodziny w sytuacji, kiedy setki, tysiące ojców i matek pracują za granicą i wychowują własne dzieci przez telefon, przy pomocy babć, sąsiadów, nie stanowi potencjalnie najlepszych warunków dla zaspokajania przez rodziców potrzeby bezpieczeństwa i miłości u ich dzieci' ${ }^{6}$ Szacuje się, że w końcu 2014 roku poza granicami Polski przebywało czasowo ok. 2320 tys. mieszkańców naszego kraju, tj. o 124 tys. (5,6\%) więcej niż w 2013 roku. Zdecydowana większość polskich emigrantów przebywa za granicą w związku z pracą, chociaż wraz z upływem czasu zwiększa się odsetek członków rodzin polskich emigrantów, pozostających na ich utrzymaniu (małżonkowie, dzieci) ${ }^{7}$.

Współcześnie dostrzegamy zmiany roli, jaką rodzina i rodzice odgrywają w zakresie funkcji socjalizacyjnej w stosunku do społeczeństwa. W rodzinie tradycyjnej młode osoby wdrażano do życia w społecznej rzeczywistości w ramach wielopokoleniowej rodziny. Współcześnie w socjalizację dziecka angażują się inne podmioty i instytucje. W celu wsparcia rodziców, obciążonych pracą i działaniami społecznymi, wiele czynności przejęły żłobki, przedszkola, szkoły, służba zdrowia, internaty, domy kultury, rodziny zastępcze. Dostęp do tych instytucji jest ograniczony ze względu na status ekonomiczny rodziny czy jej miejsce zamieszkania. Pomimo bogatej gamy różnych instytucji wspomagających rodzinę w funkcji socjalizacyjnej właściwa socjalizacja dziecka w domu rodzinnym stwarza niepowtarzalne okazje do samorealizacji, rozwoju samodzielności, a więc wykonywania przez dziecko wielu czynności. Stanisław Wielgus wyraża przekonanie, że rodzina nadal pełni rolę fundamentu życia społecznego, „a silne, trwałe i godne zaufania struktury rodzinne są główną potrzebą współczesnych społeczeństw i kultur, i to zarówno z biologicznego, jak również

5 Z. Frączek, Pokoleniowe przemiany społecznej świadomości wartości rodziny, Rzeszów 2011, s.11-12. H. Cudak, Zagrożenia emocjonalne i społeczne dzieci z rodzin rozwiedzionych, Toruń 2010, s. 8-9.

6 D. Tomczyszyn, Społeczne problemy funkcjonowania osób z upośledzeniem umysłowym w opinii mieszkańców powiatu bialskiego, Biała Podlaska 2009, s. 18.

7 stat.gov.pl/.../szacunek_emigracji_z_polski_w_latach_2004-2014, s. 3 (15.12.2015). 
z etycznego, socjalnego, a nawet politycznego, ekonomicznego i ekologicznego punktu widzenia"s.

\section{Upośledzenie intelektualne - ustalenia terminologiczne}

Według wyników Narodowego Spisu Powszechnego Ludności i Mieszkań z 2011 roku w Polsce żyje około 4,7 mln (dokładnie 4 697,0 tys.) osób niepełnosprawnych ${ }^{9}$. Artykuł dotyczy rodzin wychowujących dziecko z niepełnosprawnością intelektualną, co wymaga pewnych ustaleń terminologicznych.

Zdaniem Aleksandra Hulka, termin „upośledzenie należy odnosić przede wszystkim do konsekwencji zaistniałej niepełnosprawności i rozumieć jako «łączny rezultat przeszkód, które inwalidztwo spiętrza między jednostką dotkniętą nim, a osiągnięciem przez nią maksymalnego poziomu funkcjonowania»"10. W takim rozumieniu pojęcie upośledzenia wymaga sprecyzowania w kontekście analizowanego zjawiska. Z pojęciem upośledzenia stykamy się bowiem w dwojakim tego słowa rozumieniu. Jedno z nich obrazuje upośledzenie o charakterze funkcjonalnym, zachodzące w obrębie fizycznych lub psychicznych czynności danej jednostki i sprawiające, iż osiągane przez nią wyniki są poniżej tych, które osiągają osoby uchodzące za normalne. Tak ujmowane pojęcie odnosi się do powszechnie używanego określenia „upośledzenia umysłowego”, stosowanego do dzieci, dorosłych i młodzieży ze specyficznym rodzajem deficytów intelektualnych. Termin ten może mieć jednak i inne, społeczne konotacje. W drugim tego słowa znaczeniu „upośledzenie” rozumiane jest przede wszystkim jako zdeklasowanie jednostki jako gorszej od innych członków grupy społecznej. W niniejszym opracowaniu akcentuje się pierwsze znaczenie upośledzenia, chociaż uwaga zostanie zwrócona również na społeczne definiowanie upośledzenia.

Upośledzenie umysłowe wiąże się z trwałymi zmianami w ośrodkowym układzie nerwowym oraz z różnymi rodzajami zaburzeń w jego funkcjonowaniu. Globalny charakter defektu to przyczyna zaburzeń sfery intelektualnej, emocjonalnej, społecznej i motorycznej. Utrudnia to, czasami wręcz uniemożliwia proces uczenia się i przystosowania społecznego osoby upośledzonej umysłowo. Istnieją różne podejścia do definiowania pojęcia oligofrenii. Wyróżnia się wśród nich m.in.: klasyfikację biomedyczną, partą na czynnikach medycznych; klasyfikację

8 S. Wielgus, Rodzina wobec wspótczesnych zagrożeń, [w:] Rodzina źródło życia i szkota miłości, red. D. Kornas-Biela, Lublin 2001, s. 16.

9 http://stat.gov.pl/cps/rde/xbcr/gus/lud_raport_z_wynikow_NSP2011.pdf, s. 63 (15.12.2015).

10 A. Hulek, Teoria i praktyka rehabilitacji inwalidów, Warszawa 1969, s. 17. 
według kryterium ewolucyjnego, opartą na porównaniu poziomu intelektualnego osoby z niepełnosprawnością intelektualną z poziomem dziecka w normie intelektualnej i na stwierdzeniu pewnej równowagi. W klasyfikacji społecznej podkreśla się zdolności osoby z niepełnosprawnością intelektualną do zaspokajania swoich potrzeb; natomiast w podejściu pedagogicznym wyróżnia się dzieci małowyuczalne, dzieci wyuczalne, dzieci szkolne. Największym uznaniem cieszy się definicja DSM-IV - Amerykańskiego Towarzystwa Psychiatrycznego, która ustala, że cechą upośledzenia umysłowego jest istotnie niższy ogólny poziom funkcjonowania intelektualnego (kryterium A), który współwystępuje przy znacznych ograniczeniach w zachowaniu przystosowawczym w przynajmniej dwóch następujących obszarach zdolności: 1) porozumiewanie się, 2) troska o siebie, 3) tryb życia domowego, 4) sprawności społeczno-interpersonalne, 5) korzystanie ze środków zabezpieczenia społecznego, 6) kierowanie sobą, 7) troska o zdrowie i bezpieczeństwo, 8) zdolności szkolne, 9) sposób organizowania czasu wolnego i pracy (kryterium B), stan ten powinien wystąpić przed 18. rokiem życia (kryterium C).

Celem podstawowym rozwoju społecznego osoby z upośledzeniem umysłowym, bez względu na stopień upośledzenia, jest rozwój samodzielności, personalizacji i socjalizacji. Ramy ingerencji społecznej i pedagogicznej wyznaczają indywidualne możliwości tej osoby. Wiele osób z upośledzeniem umysłowym kończy szkoły zawodowe, są one cenionymi pracownikami zakładów pracy chronionej i innych, funkcjonują samodzielnie w życiu zawodowym i prywatnym. Uzyskują bardzo dobre wyniki na egzaminach kompetencyjnych, operując wiedzą z języka polskiego, matematyki, geografii, fizyki, informatyki, chemii, biologii i innych przedmiotów. Są też takie osoby z upośledzeniem umysłowym, które osiągnęły wiele w ramach systemu edukacji, a jednak nigdy nie będą samodzielnie funkcjonowały w życiu społecznym ${ }^{11}$.

\section{Rodzina z dzieckiem z niepełnosprawnościa intelektualna}

Granice możliwości osoby upośledzonej umysłowo tkwią nie tylko w niej samej. W dużym stopniu zależą od rodziny, która powinna stwarzać warunki do możliwie najpełniejszego rozwoju potencjału dziecka $\mathrm{z}$ niepełnosprawnością intelektualną.

Dziecko z upośledzeniem umysłowym potrzebuje od rodziców specjalnej pomocy, proporcjonalnej do rodzaju i stopnia upośledzenia. Wymaga indy-

11 D. Tomczyszyn, Rodzina $z$ dzieckiem niepetnosprawnym intelektualnie $w$ wymiarze społecznym i ekonomicznym, Biała Podlaska 2011, s. 23. 
widualnego traktowania, a jego rozwój w znacznym stopniu zależy od warunków środowiskowych i właściwego zaspokajania przez rodziców jego potrzeb. Stworzenie dziecku z niepełnosprawnością intelektualną optymalnych warunków rozwoju wymaga dużej kultury pedagogicznej rodziców, wyrażającej się akceptacją dziecka, odpowiedzialnością za jego rozwój, umiejętnością zaspokajania jego potrzeb. Konieczne jest, by rodzice zrozumieli, że obok potrzeb występujących u wszystkich dzieci ma ono dodatkowe, specyficzne potrzeby, które należy zaspokoić. I przeciwnie, „rodzice, którzy przeżywają konflikty, są nerwowi i często ze sobą skłóceni, nie tylko nie zapewniają dziecku bezpieczeństwa, lecz mogą wpływać hamująco na jego rozwój”'12.

Życie z dzieckiem niepełnosprawnym wymaga wysokiego poziomu zaangażowania, bycia czujnym, przystosowania mieszkania, jak i własnego życia osobistego do niepełnosprawności dziecka. Rodzina daje dziecku niepełnosprawnemu wsparcie i stabilizację w życiu. Anna Konieczna, pisząc o rodzinach wychowujących dziecko z niepełnosprawnością, twierdzi: „życie [...] wypełnione bywa niekończącymi się trudnymi do rozwiązania problemami, to właśnie rodzina podejmuje funkcje opiekuńcze (zgodnie z oczekiwaniami społecznymi i przy aktualnym niedomaganiu innego modelu). [...] W rodzinie tkwi potencjał wspomagania i pomocy, z którego może czerpać osoba niepełnosprawna. [...] Rodzice walczą o miejsce w życiu i w społeczeństwie dla swoich dzieci, które «dożywotnia» niepełnosprawność uzależnia w różnym stopniu od opieki i pomocy innych"13.

Sukcesy małe i duże w pokonywaniu trudności dnia codziennego, obserwacja rozwoju dziecka stają się także źródłem radości rodziców. Rodzice są dumni z dziecka, przepełnia ich miłość do niego, akceptują jego niepełnosprawność, a rodzicielstwo to posiada wymiar trudnego i wspaniałego zarazem.

\section{Cel pracy}

Funkcjonowanie rodziny niesie ze sobą dużo radości, ale także wymaga radzenia sobie $\mathrm{z}$ różnorodnymi trudnościami. Wiele $\mathrm{z}$ nich może być natury materialnej i ekonomicznej. Wątpliwości może budzić wybór systemu edukacyjnego czy szukanie informacji o wsparciu i pomocy dziecku. Wiele wysiłku muszą rodzice włożyć, zanim leczenie i rehabilitacja dziecka zaczną przynosić efek-

12 S. Tucholska, Percepcja rodziców przez dzieci upośledzone w stopniu lekkim, „Szkoła Specjalna" (1998) nr 3.

13 A. Konieczna, Dążenia rodziców do aktywizacji zawodowej dzieci z niepetnosprawnościa - lęk o przyszłość, [w:] Aktywność zawodowa osób z niepetnosprawnością, red. D. Tomczyszyn, W. Romanowicz, Biała Podlaska 2012, s. 277. 
ty. Aby udzielić właściwego wsparcia rodzinom, zrozumieć specyfikę ich funkcjonowania, należy jak najdokładniej te trudności zdiagnozować. Celem pracy badawczej było zdiagnozowanie trudności, które dostrzegają rodzice dzieci $\mathrm{z}$ niepełnosprawnością intelektualną.

W ramach realizacji badań postawiono następujący problem badawczy: Jakie trudności w opiece i wychowaniu dziecka z niepełnosprawnością intelektualną dostrzegają jego rodzice?

\section{Materiał i metoda}

Podstawową metodą zbierania danych był sondaż diagnostyczny, w którego ramach wykorzystano kwestionariusz ankiety. W skonstruowanym przez badacza narzędziu wystąpiły różne kategorie pytań i odpowiedzi. Oprócz typowych pytań z zamkniętą i półotwartą kafeterią wykorzystano wiele pytań ze skalą Likerta. Ten typ pytań umożliwił określenie nasilenia badanej cechy lub zjawiska ${ }^{14}$.

\section{Organizacja badań, charakterystyka badanej grupy}

Badania realizowano w 2013 i 2014 roku. Przebadano 222 rodziców dzieci z niepełnosprawnością intelektualną w stopniu umiarkowanym i znacznym, w tym 111 matek i 111 ojców. Badanie przeprowadzono w trzech powiatach: bialskim, łukowskim i lubartowskim. Starano się, aby liczba rodziców z poszczególnych powiatów była zbliżona do siebie. Próbę (konkretne rodziny) dobrano w sposób celowy. Wzięto pod uwagę miejsce zamieszkania, stan cywilny rodziców, wiek i stopień niepełnosprawności intelektualnej dziecka. Starano się, aby rodzice zamieszkiwali zarówno w miastach, jak i w środowisku wiejskim w porównywalnych częściach.

Przebadano rodziców wychowujących dzieci tylko z umiarkowanym lub znacznym stopniem niepełnosprawności intelektualnej. Połowa dzieci posiadała umiarkowany stopień niepełnosprawności, druga połowa znaczny stopień niepełnosprawności. Osoby biorące udział w badaniu posiadały dzieci w wieku przedszkolnym i szkolnym. Wyselekcjonowana do badań grupa rodzin zawierała osoby będące w związkach małżeńskich. Nie badano osób samotnie wychowujących dziecko, rozwiedzionych czy żyjących w związkach partnerskich. Wiek rodziców przedstawia tabela nr 1.

14 M. Łobocki, Metody badań pedagogicznych, Warszawa 1982. 
Tabela 1. Wiek rodziców

\begin{tabular}{|c|c|c|c|c|c|c|c|c|}
\hline \multirow{2}{*}{$\begin{array}{c}\text { Grupy } \\
\text { rodziców }\end{array}$} & \multicolumn{7}{|c|}{ Wiek w latach } \\
\cline { 2 - 9 } & & $16-25$ & $26-35$ & $36-45$ & $46-55$ & $56-65$ & $\begin{array}{c}\text { powy- } \\
\text { żej 65 }\end{array}$ & razem \\
\hline \multirow{2}{*}{ matki } & $\mathrm{L}$ & 6 & 1 & 44 & 38 & 9 & 2 & 111 \\
\cline { 2 - 9 } & $\%$ & $5,4 \%$ & $10,8 \%$ & $39,6 \%$ & $34,2 \%$ & $8,1 \%$ & $1,8 \%$ & $100 \%$ \\
\hline \multirow{2}{*}{ ojcowie } & $\mathrm{L}$ & 5 & 10 & 41 & 40 & 12 & 3 & 111 \\
\cline { 2 - 10 } & $\%$ & $4,5 \%$ & $9,0 \%$ & $36,9 \%$ & $36,0 \%$ & $10,8 \%$ & $2,7 \%$ & $100 \%$ \\
\hline \multirow{2}{*}{ razem } & $\mathrm{L}$ & 11 & 22 & 85 & 78 & 21 & 5 & 222 \\
\cline { 2 - 9 } & $\%$ & $5,0 \%$ & $9,9 \%$ & $38,3 \%$ & $35,1 \%$ & $9,5 \%$ & $2,3 \%$ & $100 \%$ \\
\hline
\end{tabular}

Zdecydowaną większość badanej grupy stanowili rodzice w wieku 36-55 lat. Z tabeli wynika, że w tym wieku było 73,9\% matek, 73\% ojców, czyli 73,4\% badanych rodziców. Wykres nr 1 ilustruje odsetek rodziców zamieszkałych w mieście i na wsi.

Wykres 1. Miejsce zamieszkania rodziców (\%)

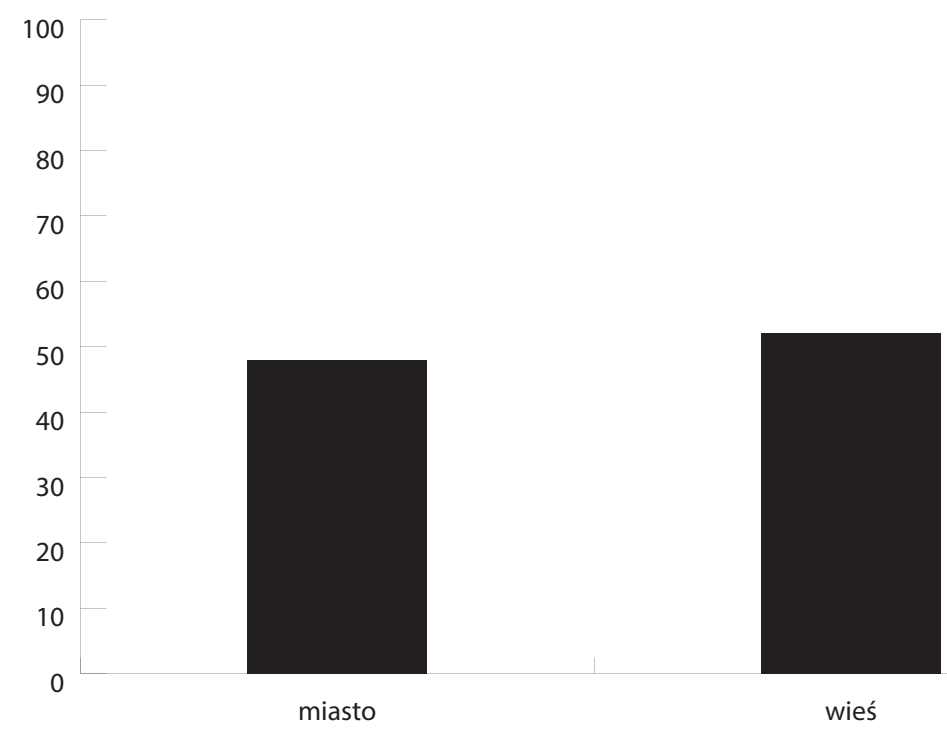

Źródło: badania własne. 
Na podstawie wykresu można stwierdzić, że 47,9\% rodziców mieszkało w miastach, zaś 52,1\% rodziców zamieszkiwało tereny wiejskie.

Wykształcenie rodziców jest bezpośrednio związane z szansą uzyskania pracy, a także materialnymi uwarunkowaniami funkcjonowania rodziny, co obrazuje tabela nr 2 .

Tabela 2. Wykształcenie rodziców

\begin{tabular}{|c|c|c|c|c|c|c|c|c|}
\hline \multirow[b]{2}{*}{$\begin{array}{c}\text { Grupy } \\
\text { rodziców }\end{array}$} & \multicolumn{8}{|c|}{ Stopień wykształcenia } \\
\hline & & 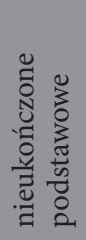 & 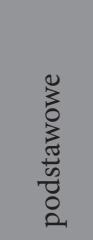 & 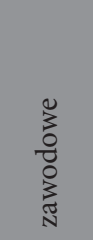 & 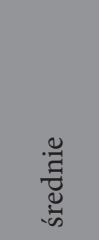 & 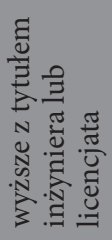 & 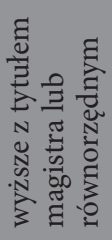 & $\begin{array}{l}\text { घี } \\
\text { స్ }\end{array}$ \\
\hline \multirow{2}{*}{ matki } & $\mathrm{L}$ & 1 & 16 & 46 & 30 & 9 & 9 & 111 \\
\hline & $\%$ & $0,9 \%$ & $14,4 \%$ & $41,4 \%$ & $27,0 \%$ & $8,1 \%$ & $8,1 \%$ & $100 \%$ \\
\hline \multirow{2}{*}{ ojcowie } & $\mathrm{L}$ & 1 & 19 & 46 & 32 & 6 & 7 & 111 \\
\hline & $\%$ & $0,9 \%$ & $17,1 \%$ & $41,4 \%$ & $28,8 \%$ & $5,4 \%$ & $6,3 \%$ & $100 \%$ \\
\hline \multirow{2}{*}{ razem } & $\mathrm{L}$ & 2 & 35 & 92 & 62 & 15 & 16 & 222 \\
\hline & $\%$ & $0,9 \%$ & $15,8 \%$ & $41,4 \%$ & $27,9 \%$ & $6,8 \%$ & $7,2 \%$ & $100 \%$ \\
\hline
\end{tabular}

Najczęściej rodzice legitymowali się wykształceniem na poziomie szkoły zawodowej (41,4\% badanej grupy). Następną grupę stanowili rodzice posiadający średnie wykształcenie - $27,9 \%$ rodzin. Kolejną grupą byli rodzice o podstawowym lub niższym wykształceniu $-16,7 \%$ rodziców. Niestety najmniej rodziców posiadało stopień licencjata lub wykształcenie wyższe z tytułem, stanowili oni około $14 \%$ wszystkich badanych rodziców. Korzystając z testu istotności różnic Chi kwadrat Pearsona nie stwierdzono istotnych statystycznie różnic między wykształceniem matek i ojców $(\mathrm{p}=0,948)$.

Niestety wykształcenia badanych rodziców nie można ocenić pozytywnie. Konsekwencje niskiego wykształcenia rodziców to często problemy z uzyskaniem dobrze płatnej pracy, co wpływa na niski status materialny rodziny i rzutuje na brak możliwości pełnego rozwoju niepełnosprawnego dziecka (np. ogra- 
niczenia w korzystaniu z kultury, ograniczenia w wyjazdach wakacyjnych, rozwoju zainteresowań i inne).

Liczbę i wiek dzieci w badanych rodzinach prezentuje tabela nr 3.

Tabela 3. Liczba i wiek dzieci z niepełnosprawnością

\begin{tabular}{|c|c|c|}
\hline Wiek & Liczba & Odsetek (\%) \\
\hline 5-7 lat & 5 & $2,3 \%$ \\
\hline $8-10$ lat & 13 & $10,9 \%$ \\
\hline $11-13$ lat & 15 & $12,6 \%$ \\
\hline $14-17$ lat & 36 & $30,3 \%$ \\
\hline $18-28$ lat & 50 & $42,0 \%$ \\
\hline Razem & 119 & $100,0 \%$ \\
\hline
\end{tabular}

Dzieci z niepełnosprawnością były w wieku od 5 do 28 lat. Po $42 \%$ to dzieci od 11 do 17 lat i od 18 do 28 lat. 13\% grupy to dzieci małe, w wieku przedszkolnym i w wieku nauczania integracyjnego.

W badanej grupie przeważały osoby, które posiadały jedno dziecko niepełnosprawne (93,7\% grupy, 104 rodziny). W sześciu rodzinach opiekowano się dwojgiem dzieci z niepełnosprawnością $(5,41 \%)$, jedna $\mathrm{z}$ rodzin posiadała troje dzieci posiadających niepełnosprawność intelektualną (0,9\%).

W sumie badane osoby opiekowały się 119 dziećmi z niepełnosprawnością intelektualną. W tej grupie dzieci znajdowało się 60 dzieci z niepełnosprawnością umiarkowaną i 59 dzieci ze znacznym stopniem niepełnosprawności.

Rodzice ocenili sytuację materialną rodziny - tabela nr 4 .

Tabela 4. Ocena sytuacji materialnej rodziny

\begin{tabular}{|l|c|c|c|c|c|c|}
\hline \multirow{2}{*}{$\begin{array}{c}\text { Ocena sytuacji materialnej } \\
\text { rodziny }\end{array}$} & \multicolumn{2}{|c|}{ Rodzice } & \multicolumn{2}{c|}{ Matki } & \multicolumn{2}{c|}{ Ojcowie } \\
\cline { 2 - 7 } & $\mathrm{L}$ & $\%$ & $\mathrm{~L}$ & $\%$ & $\mathrm{~L}$ & $\%$ \\
\hline bardzo dobra & 9 & $4,1 \%$ & 7 & $6,3 \%$ & 2 & $1,8 \%$ \\
\hline dość dobra & 53 & $23,9 \%$ & 25 & $22,5 \%$ & 28 & $25,2 \%$ \\
\hline
\end{tabular}




\begin{tabular}{|l|c|c|c|c|c|c|}
\hline \multirow{2}{*}{$\begin{array}{c}\text { Ocena sytuacji materialnej } \\
\text { rodziny }\end{array}$} & \multicolumn{2}{|c|}{ Rodzice } & \multicolumn{2}{c|}{ Matki } & \multicolumn{2}{c|}{ Ojcowie } \\
\cline { 2 - 7 } & $\mathrm{L}$ & $\%$ & $\mathrm{~L}$ & $\%$ & $\mathrm{~L}$ & $\%$ \\
\hline przeciętna & 126 & $56,8 \%$ & 63 & $56,8 \%$ & 63 & $56,8 \%$ \\
\hline raczej zła & 29 & $13,1 \%$ & 15 & $13,5 \%$ & 14 & $12,6 \%$ \\
\hline zdecydowanie zła & 5 & $2,3 \%$ & 1 & $0,9 \%$ & 4 & $3,6 \%$ \\
\hline Razem & 222 & $100,0 \%$ & 111 & $100,0 \%$ & 111 & $100,0 \%$ \\
\hline
\end{tabular}

Ponad połowa rodziców oceniła sytuację materialną rodziny jako przeciętną. O złej sytuacji mówiło $13 \%$ badanych, w tym 2,3\% twierdziło, że jest ona bardzo zła. Natomiast jako dobrą sytuację materialną swojej rodziny oceniło $28 \%$ badanych, w tym bardzo dobrą tylko 4,1\% rodziców. Podobnie oceniali sytuacje swoich rodzin ojcowie i matki biorący udział w badaniach.

Na wykresie nr 2 ukazane są opinie rodziców na temat tego, czy posiadane dochody wystarczają na zaspokojenie podstawowych potrzeb rodziny.

W tym kontekście nie dziwi fakt, że 142 badanych (63\%) uważało, że posiadane dochody nie pozwalają na zaspokojenie bieżących potrzeb. Przeciwną

Wykres 2. Czy Pan/i zdaniem dochody pozwalają na zaspokojenie bieżących potrzeb? 100

90

80

70

60

50

40

30

20

10

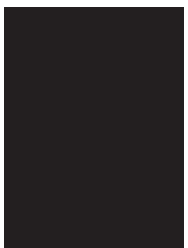

tak

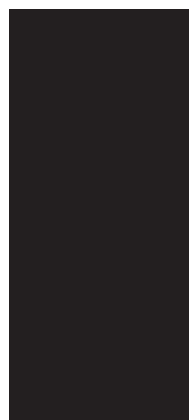

nie

Źródło: badania własne. 
Wykres 3. Suma wyborów - podstawowe źródła dochodów

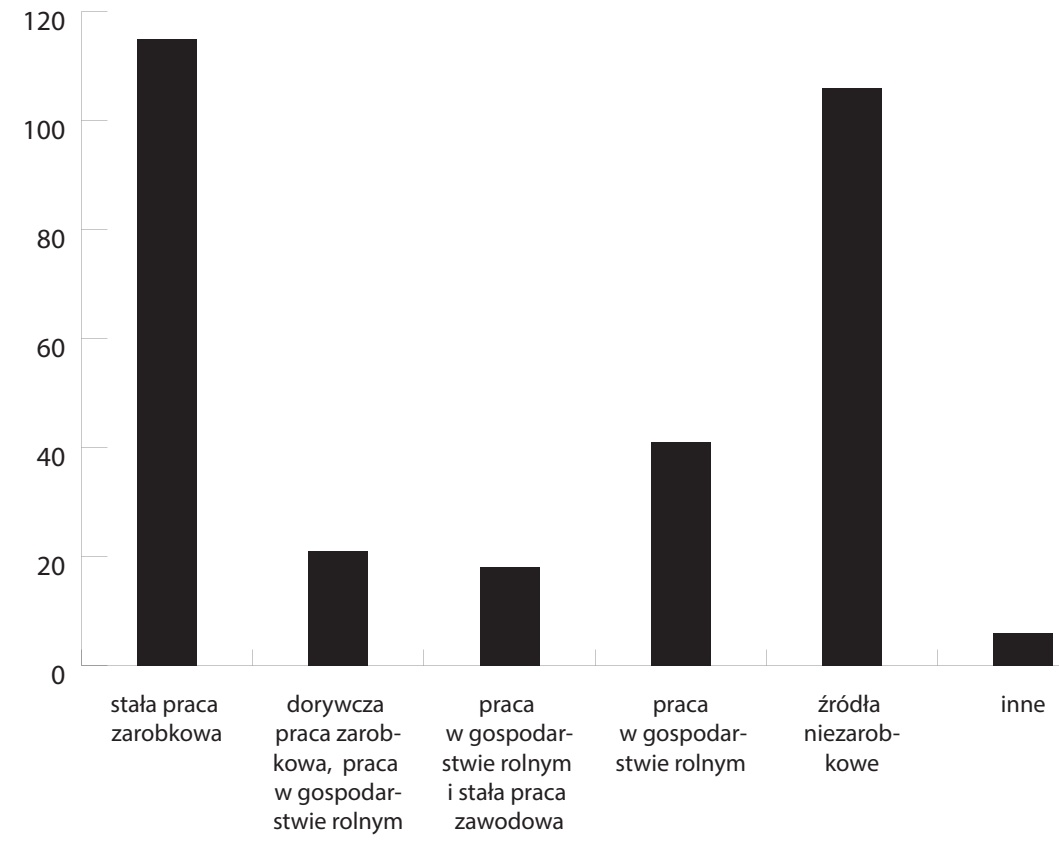

Źródło: badania własne.

opinię wyraziło zaledwie 80 osób (36,9\%). Ocena sytuacji materialnej z reguły wśród badanych jest klasyfikacją typowo subiektywną, jednak zauważalna asymetria pomiędzy ocenami pozytywnymi i negatywnymi uświadamia nam trudną sytuację materialną rodzin z dzieckiem niepełnosprawnym, żyjących na terenach Lubelszczyzny.

Zapytano rodziców wychowujących niepełnosprawne dzieci o podstawowe źródła dochodów (wykres nr 3). Badani posiadali możliwość wielokrotnego wyboru odpowiedzi.

Okazuje się, że rodziny utrzymywały się z dwóch źródeł. Były nimi praca zawodowa (115 rodziców) oraz zasiłki, system rent i emerytur (źródła niezarobkowe - 106 osób). Pracę w gospodarstwie rolnym wskazało 41 osób. Kolejne 21 osób łączyło pracę w gospodarstwie z pracą zawodową. Niewielu rodziców było aktywnych zawodowo, na ten stan mogło mieć wpływ niskie wykształcenie badanych lub opieka nad niepełnosprawnym dzieckiem. Potwierdzenie tej tezy wymaga jednak dalszych badań. Standard mieszkania ilustruje tabela nr 5. 
Tabela 5. Standard mieszkania

\begin{tabular}{|c|l|c|c|c|c|}
\hline \multirow{2}{*}{ lp. } & \multirow{2}{*}{ Standard mieszkania } & \multicolumn{2}{|c|}{ jest } & \multicolumn{2}{c|}{ brak } \\
\cline { 3 - 6 } & & $\mathrm{L}$ & $\%$ & $\mathrm{~L}$ & $\%$ \\
\hline 1 & woda bieżąca & 216 & $97,7 \%$ & 5 & $2,3 \%$ \\
\hline 2 & woda bieżąca ciepła & 174 & $78,7 \%$ & 47 & $21,3 \%$ \\
\hline 3 & centralne ogrzewanie & 199 & $90,0 \%$ & 22 & $10,0 \%$ \\
\hline 4 & kanalizacja & 179 & $81,0 \%$ & 42 & $19,0 \%$ \\
\hline
\end{tabular}

Ponad $97 \%$ grupy miało dostęp do bieżącej wody, 78,7\% posiadało stały dostęp do ciepłej wody. Centralne ogrzewanie posiadało 90\% kobiet. Kanalizacja funkcjonowała w domach $81 \%$ rodzin.

Podsumowując przedstawioną charakterystykę można stwierdzić, że badani rodzice posiadali zazwyczaj posiadali jedno dziecko z niepełnosprawnością, połowa $\mathrm{z}$ nich zamieszkiwała na wsi, połowa w mieście, legitymowali się najczęściej średnim i niższym wykształceniem, niewielu z nich było aktywnych zawodowo. Twierdzili, że ich dochody nie pozwalają na zaspokojenie bieżących potrzeb, a swoją sytuację materialną określali jako przeciętną.

\section{Wyniki badań}

Pytanie dotyczące trudności w realizacji ról rodzicielskich rodziców dzieci z niepełnosprawnością intelektualną posiadało charakter pytania wielokrotnego wyboru, co spowodowało, że liczby przekraczają 100\%. Otrzymane wypowiedzi zaprezentowano na wykresie nr 4.

Połowa rodziców największe trudności dostrzegała w realizacji zadań związanych z wychowaniem dziecka z niepełnosprawnością. Jednak 35\% rodziców wskazało, że trudności dotyczą także obowiązków opiekuńczych. Blisko co trzeci badany rodzic deklarował trudności w zakresie prowadzenia gospodarstwa domowego oraz pracy zawodowej. Role zawodowe częściej zaznaczali ojcowie dzieci, w pozostałych sferach życia większe trudności deklarowały w badanych rodzinach matki. Największe różnice między rodzicami wystąpiły w ocenie roli opiekuna dziecka, w której 38\% matek i 32\% ojców widziało największe trudności. W dwóch kategoriach trudności wykazano zależność od wieku rodziców (tabela nr 6). 
Wykres 4. Trudności w realizacji ról rodzinnych (\%)

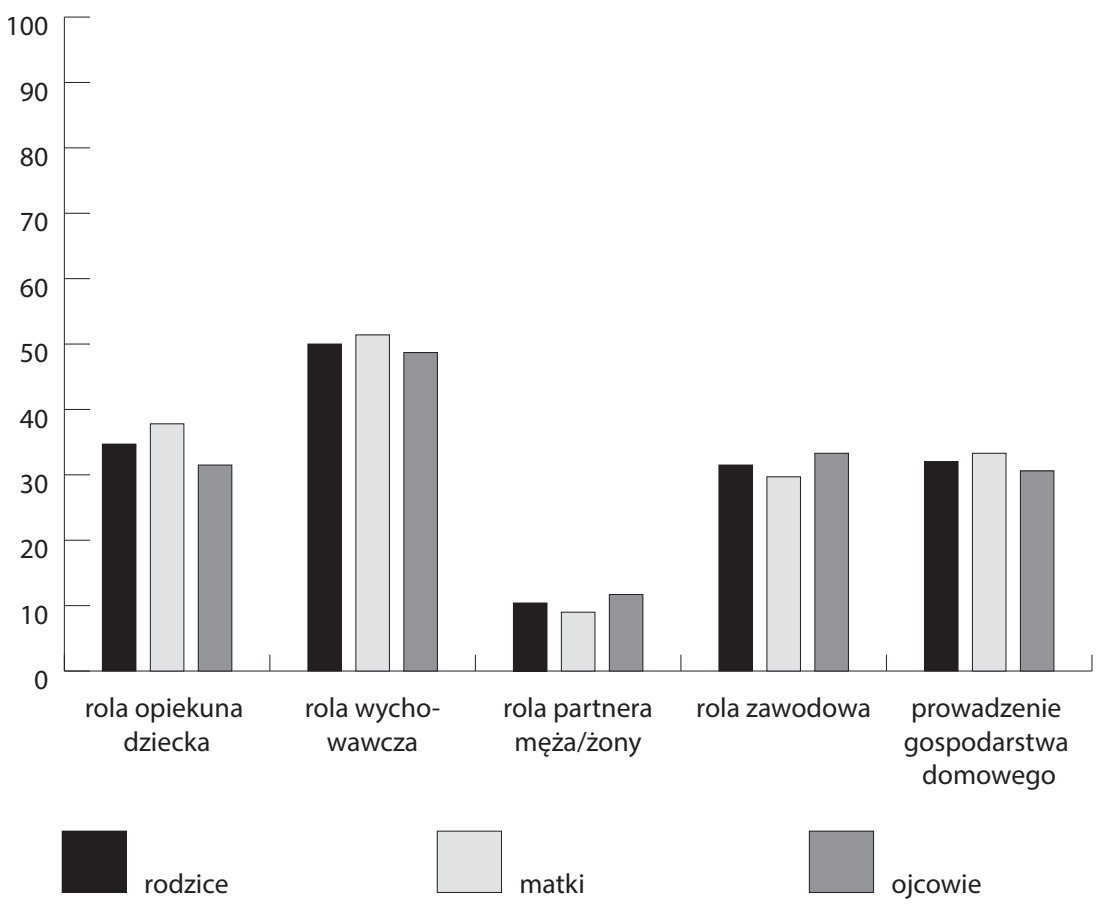

Źródło: badania własne.

Tabela 6. Trudności w realizacji ról a wiek badanych

\begin{tabular}{|c|c|c|c|c|c|c|c|c|}
\hline \multirow{2}{*}{$\begin{array}{c}\text { Wybrane kategorie } \\
\text { ról rodzicielskich }\end{array}$} & \multicolumn{2}{|c|}{ Do 35 lat } & \multicolumn{2}{|c|}{$36-45$ lat } & \multicolumn{2}{|c|}{$46-55$ lat } & \multicolumn{2}{|c|}{ Ponad 55 lat } \\
\cline { 2 - 10 } & $\mathrm{L}$ & $\%$ & $\mathrm{~L}$ & $\%$ & $\mathrm{~L}$ & $\%$ & $\mathrm{~L}$ & $\%$ \\
\hline $\begin{array}{l}\text { rola wychowawcza, } \\
\text { Chi kwadrat Pearsona } \\
8,062 \mathrm{df}=3, \mathrm{p}=0,044\end{array}$ & 119 & $54,1 \%$ & 114 & $51,5 \%$ & 102 & $46,2 \%$ & 102 & $46,2 \%$ \\
\hline $\begin{array}{l}\text { prowadzenie gospo- } \\
\text { darstwa domowego, } \\
\begin{array}{l}\text { Chi kwadrat Pearsona } \\
9,608 \mathrm{df}=3, \mathrm{p}=0,222\end{array}\end{array}$ & 75 & $34,1 \%$ & 87 & $39,4 \%$ & 45 & $20,5 \%$ & 111 & $50,0 \%$ \\
\hline
\end{tabular}

Im starsi rodzice, tym rzadziej wskazywali trudności w realizacji roli wychowawczej, ponadto w grupach wiekowych ponad 55 lat i 36-45 lat istotnie częściej deklarowano trudności w prowadzeniu gospodarstwa domowego. 
Zapytano badanych, jakie trudności są najbardziej odczuwalne w opiece i wychowaniu dziecka niepełnosprawnego (tabela nr 7). Rodzice mogli wybrać trzy grupy trudności, jakie są najbardziej odczuwalne w codziennym wychowywaniu dziecka z niepełnosprawnością, lub dopisać własną odpowiedź. Badani dokonali 656 wyborów, w tym 219 na pierwszym miejscu, 202 na drugim miejscu i 156 na trzecim miejscu.

Tabela 7. Trudności rodziców dziecka z niepełnosprawnością

\begin{tabular}{|l|c|c|c|c|c|c|c|c|}
\hline \multirow{2}{*}{ Rodzaj trudności } & \multicolumn{4}{|c|}{$\begin{array}{c}\text { Trudność wybierana } \\
\text { na I, II, III miejscu }\end{array}$} & \multicolumn{4}{c|}{ Trudność wybierana } \\
\cline { 2 - 9 } & I & II & III & $\begin{array}{c}\text { Suma } \\
\text { n) }\end{array}$ & 1 & 2 & 3 & $\begin{array}{c}\text { Suma } \\
(\%)\end{array}$ \\
\hline w opiece zdrowotnej & 50 & 17 & 12 & 79 & $22,7 \%$ & $8,4 \%$ & $7,7 \%$ & $12 \%$ \\
\hline $\begin{array}{l}\text { w opiece } \\
\text { rehabilitacyjnej }\end{array}$ & 42 & 40 & 17 & 178 & $19,1 \%$ & $19,8 \%$ & $10,9 \%$ & $27,1 \%$ \\
\hline $\begin{array}{l}\text { związane z edukacją } \\
\text { trudności wynikające } \\
\text { z traktowania osób } \\
\text { niepełnosprawnych }\end{array}$ & 23 & 32 & 26 & 81 & $10,5 \%$ & $15,8 \%$ & $16,7 \%$ & $12,3 \%$ \\
\hline $\begin{array}{l}\text { bariery } \\
\text { architektoniczne }\end{array}$ & 9 & 12 & 12 & 33 & $4,1 \%$ & $5,9 \%$ & $7,7 \%$ & $5,0 \%$ \\
\hline $\begin{array}{l}\text { w zdobywaniu } \\
\text { informacji } \\
\text { o niepełnosprawności } \\
\text { i prawach osób } \\
\text { niepełnosprawnych }\end{array}$ & 16 & 30 & 28 & 74 & $7,3 \%$ & $14,9 \%$ & $17,9 \%$ & $11,3 \%$ \\
\hline $\begin{array}{l}\text { w opiece zdrowotnej } \\
\text { w op }\end{array}$ & 35 & 23 & 31 & 89 & $16,4 \%$ & $11,4 \%$ & $19,8 \%$ & $13,6 \%$ \\
\hline \begin{tabular}{l} 
Razem \\
\hline
\end{tabular} & 219 & 202 & 156 & 656 & $100,0 \%$ & $100,0 \%$ & $100,0 \%$ & $100,0 \%$ \\
\hline
\end{tabular}

Trudności wybierane na pierwszym miejscu w podziale na ojców, matki i wszystkich rodziców ukazano na wykresie nr 5.

Trudnościami najistotniejszymi, wybieranymi na pierwszym miejscu, okazały się problemy z zapewnieniem opieki zdrowotnej oraz wynikające z traktowania osoby niepełnosprawnej przez innych ludzi. Wybrało je ponad $20 \%$ badanych. Badani wskazywali kolejno na trudności w zapewnieniu opieki rehabilitacyjnej (19\% rodziców) oraz problemy ekonomiczne (19\% rodziców). Badani zwrócili uwagę na trudności związane z edukacją - takiego wyboru dokonało $10,5 \%$ badanych. Inne trudności związane $\mathrm{z}$ opieką i wychowywaniem dziec- 
Wykres 5. Największe trudności w opiece i wychowywaniu niepełnosprawnego dziecka (wybierane na pierwszym miejscu) (\%)

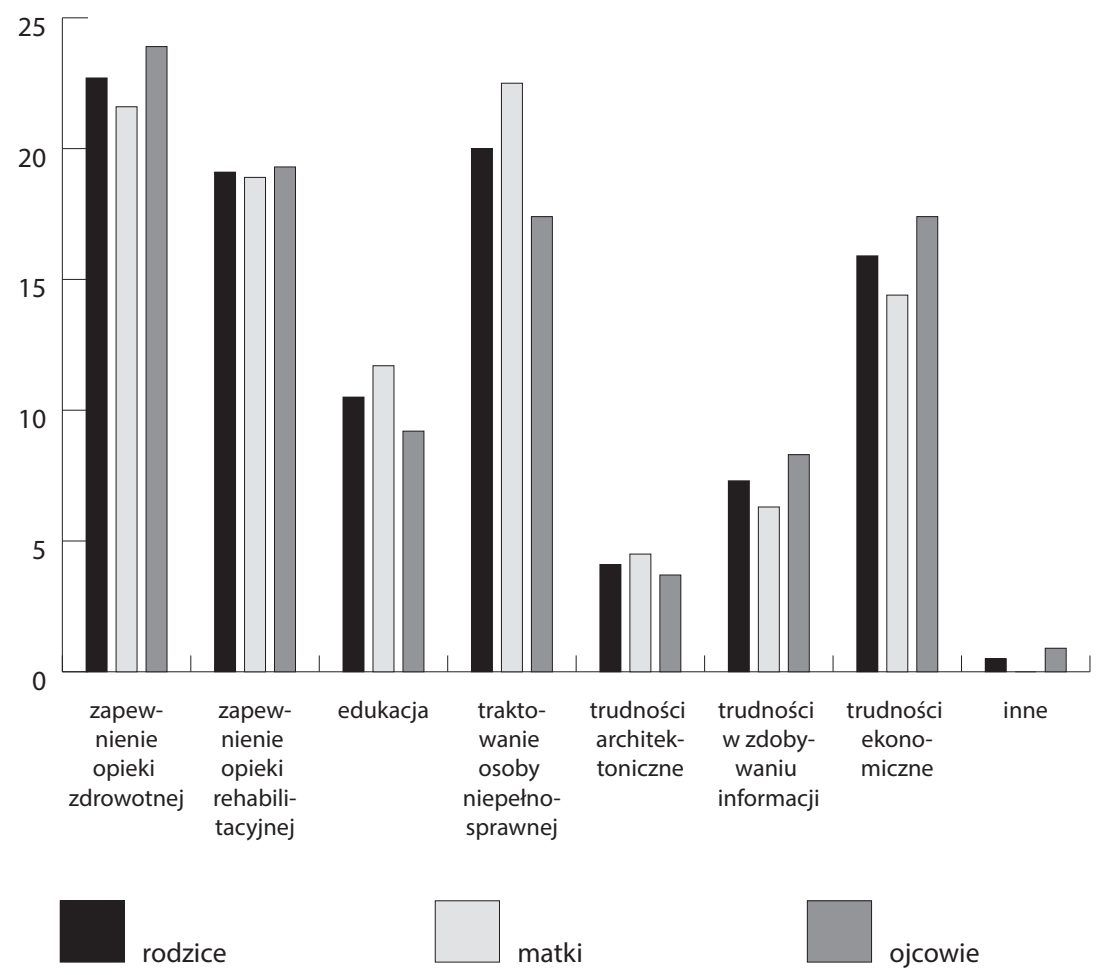

Źródło: badania własne.

ka niepełnosprawnego były wybierane rzadziej. Na przykład trudności w zdobywaniu informacji o niepełnosprawności i prawach osób niepełnosprawnych wybrało 7\% rodziców. Najrzadziej na pierwszym miejscu badani wybierali trudności wynikające z barier architektonicznych (4\% badanych).

Trudności wynikające z traktowania osoby niepełnosprawnej przez innych ludzi miały najwięcej głosów również w grupie problemów zgłaszanych na drugim miejscu. Tego wyboru dokonało $24 \%$ rodziców. Kolejnym wyborem rodziców na drugim miejscu były trudności w zapewnieniu opieki rehabilitacyjnej swojemu niepełnosprawnemu dziecku (20\% badanych). Trzecim dokonywanym wyborem były trudności związane $\mathrm{z}$ edukacją oraz w zdobywaniu informacji o niepełnosprawności i prawach osób niepełnosprawnych (15-16\% rodziców).

Podobnych wyborów dokonywali rodzice wskazując trudności na trzecim miejscu. Otóż badani najczęściej zgłosili problemy ekonomiczne (20\%) oraz wy- 
nikające z traktowania osoby niepełnosprawnej przez innych (19\% rodziców). $\mathrm{Na}$ trzecim miejscu kolejną pozycję zajęły trudności w zdobywaniu informacji o niepełnosprawności i trudności edukacyjne (17-18\% badanych). Podobnie jak w poprzednich wyborach najrzadziej wybierano trudności architektoniczne.

Kolejną czynnością badawczą było zsumowanie wszystkich dokonanych wyborów. W ten sposób otrzymano najczęściej dostrzegane trudności w funkcjonowaniu rodziców posiadających dziecko z niepełnosprawnością intelektualną. Sumując wybory z pierwszego, drugiego i trzeciego miejsca, uzyskano liczbę 656 wszystkich dokonanych wyborów. Traktując ją jako 100\%, można stwierdzić, że otrzymujemy następującą kolejność wszystkich zaznaczanych trudności:

- trudności z zapewnieniem opieki rehabilitacyjnej - 178 wyborów, $27 \%$ wszystkich wyborów;

- trudności wynikające z traktowania osoby niepełnosprawnej przez innych ludzi - 122 wybory, 19\% wszystkich wyborów;

- trudności ekonomiczne - 89 wyborów, $14 \%$ wszystkich wyborów;

- trudności związane z edukacją - 81 wyborów, $12 \%$ wszystkich wyborów;

- trudności z zapewnieniem opieki zdrowotnej - 79 wyborów, 12\% wszystkich wyborów;

- trudności w zdobywaniu informacji o niepełnosprawności i praw osób niepełnosprawnych - 74 wyborów, $11 \%$ wszystkich wyborów;

- trudności wynikające z barier architektonicznych - 33 wyborów, $8 \%$ wszystkich wyborów.

W tym przypadku trudności rodzicom sprawiało zapewnienie właściwej rehabilitacji i postawy społeczne wobec dziecka. Traktowanie dziecka z niepełnosprawnością staje się przedmiotem szczególnej troski jego rodziców.

\section{Wnioski}

Na podstawie deklaracji rodziców można stwierdzić, że badani największe trudności widzieli nie w sferze zawodowej, małżeńskiej, ale w realizacji zadań związanych $\mathrm{z}$ wychowywaniem dziecka $\mathrm{z}$ niepełnosprawnością. $\mathrm{W}$ realizacji tej roli szczególne problemy dotyczyły zapewnienia opieki zdrowotnej, rehabilitacji oraz wynikały $z$ traktowania osoby niepełnosprawnej przez innych ludzi.

Jan Paweł II powtarzał, że „przyszłość ludzkości idzie przez rodzinę”. Kształtując nowe społeczeństwo, kreując jego zasady, normy, kulturę, kształtuje się także rodzinę, warunki rozwoju i wychowania dzieci. Szczególnie dzieci specjalnej troski i ich rodzice wymagają wsparcia społecznego. W świadomości współczesnego człowieka należy budować przekonanie o wartości pomocy 
tym rodzinom, a zwłaszcza dzieciom niepełnosprawnym, wzmacniać świadomość wartości każdego człowieka bez względu na jego wygląd, zdrowie, kolor skóry, iloraz inteligencji.

\section{Bibliografia}

Bielan Z., Zagrożenia i kryzys wspótczesnej rodziny, [w:] Pedagogika rodziny na progu XXI wieku. Rozwój, przedmiot, obszary refleksji i badań, red. A. W. Janke, Toruń 2004, s. 242-248. Cudak H., Zagrożenia emocjonalne i społeczne dzieci z rodzin rozwiedzionych, Toruń 2001. Frączek Z., Pokoleniowe przemiany społecznej świadomości wartości rodziny, Rzeszów 2011. Hulek A., Teoria i praktyka rehabilitacji inwalidów, Warszawa 1969.

Konieczna A., Dążenia rodziców do aktywizacji zawodowej dzieci z niepełnosprawnościa - lęk o przyszłość, [w:] Aktywność zawodowa osób z niepetnosprawnością, red. D. Tomczyszyn, W. Romanowicz, Biała Podlaska 2012, s. 277-282.

Łobocki M., Metody badań pedagogicznych, Warszawa 1982.

Melosik Z., Kultura popularna jako czynnik socjalizacji, [w:] Pedagogika społeczna, red. B. Śliwerski, Z. Kwieciński, Warszawa 2003, s.76-86.

Tetzlaff D., Divide and conquer, popular and social control in late capitalism, "Media, Culture and Society" (1991) nr 13, s.14-15.

Tomczyszyn D., Dzieci z upośledzeniem umysłowym w środowisku szkolnym -refleksje nauczyciela, Biała Podlaska 2012.

Tomczyszyn D., Rodzina z dzieckiem niepelnosprawnym intelektualnie w wymiarze społecznym i ekonomicznym, Biała Podlaska 2011.

Tomczyszyn D., Społeczne problemy funkcjonowania osób z upośledzeniem umysłowym w opinii mieszkańców powiatu bialskiego, Biała Podlaska 2009.

Tucholska S., Percepcja rodziców przez dzieci upośledzone w stopniu lekkim, „Szkoła Specjalna” (1998) nr 3, s. 143-149.

Wielgus S., Rodzina wobec współczesnych zagrożeń, [w:] Rodzina źródło życia i szkoła miłości, red. D. Kornas-Biela, Lublin 2001, s. 16-20. 